\title{
Molotov Cocktails to Mass Marches: Strategic Nonviolence, Symbolic Violence, and the Mobilizing Effect of Riots
}

\author{
Benjamin S. Case ${ }^{1}$
}

What effects do violent protests have on social movement mobilizations? In recent decades, the field of nonviolence studies has popularized a strategic nonviolence framework to understand activist tactics. This framework is problematic in two ways. First, dominant theories argue that violent protest actions demobilize nonviolent protest. However, there is less empirical support for this claim than often assumed. Current quantitative findings on the demobilizing effects of violent protest rely on a false dichotomy between violence and nonviolence that obscures the effects of low-level violent actions. Through statistical analysis of protest trends in the US over 72 years, I show that riots have an overall mobilizing impact on nonviolent protests. Second, the strategic nonviolence framing encourages an instrumental view of tactics that is prone to miss the symbolic and emotional aspects of different types of actions. Through qualitative interviews with participants in the black bloc tactic, I explore the experiential effects of the riot, and find that rioting can have deeply empowering emotional impacts on participants, with lasting effects that sustain activists' political engagement. In combination, these results demonstrate that low-level violent actions interact with movements in more dynamic ways than dominant theories have understood. [Article copies available for a fee from The Transformative Studies Institute.E-mail address: journal@transformativestudies.org Website: http://www.transformativestudies.org (02021 by The Transformative Studies Institute. All rights reserved.]

KEYWORDS: Riots, Social Movements, Violence, Nonviolence, Anarchism.

\footnotetext{
${ }^{1}$ Benjamin S. Case is an organizer, activist, and Ph.D. candidate in the Department of Sociology at the University of Pittsburgh. Address correspondence to: to Benjamin S. Case, e-mail: benjamin.s.case@pitt.edu.

Acknowledgements: I am indebted to many comrades and colleagues for their conversations and comments. Special thanks to Tarun Banerjee, Junia Howell, and Paul Welle for their methodological feedback, and to Gillian Goldberg, Hatem Hassan, and James Alex Siebens for their edits.
} 


\section{INTRODUCTION}

As long as there has been private property, there have been angry crowds setting it on fire. It is arguably the oldest and most consistent tool in the repertoire of civil resistance. However, riots have not received the theoretical, sociological, or strategic analyses that other forms of social and political struggle have. ${ }^{2}$ Riots are not mentioned in either Mao's (1937) or Guevara's (1961) classic manuals on guerrilla warfare, nor are riots included in Alinsky's (1989) canonical manual on activist strategy. Sharp's (1973) seminal volume on nonviolent struggle mentions riots in passing, but only to associate them with other forms of "violent" conflict. Meanwhile, the sociological study of movements has largely excluded an analysis of riots in the past half century through a heavy focus on organizations and formal processes (e.g., McCarthy and Zald 1977; Snow and Benford 1988).

Despite being a topic of intense debate within movements, few studies have quantitatively investigated the interaction between more and less violent forms of unarmed mobilization. The widespread "strategic nonviolence" framework holds that violent tactics demobilize nonviolent actions, making violent actions necessarily counterproductive. However, this argument is based on outmoded theories and is supported by research that does not actually speak to the question at hand (Case 2018). In this paper, I aim to empirically address this problem.

I ask two related questions: first, what effects do violent protests have on social movement mobilizations? To address this question, I interrogate the relationship between riots and nonviolent demonstrations in the US over time using quantitative analysis of a prominent timeseries dataset, finding that riots are associated with increased movement mobilizations. Second: what effects do violent protests have on participants? In Black Bloc, White Riot, AK Thompson explicates the riot in terms of political consciousness, framing the experiential violence of rioting as a heuristic through which activists begin "to move away from representational coordinates of the society of control and toward the uncharted territory of post-representational politics" (2010: 20). Following Thompson, I interview activists who have participated in

\footnotetext{
${ }^{2}$ In addition to AK Thompson's Black Bloc, White Riot (2010), other sources of research and theory on riots in movements include Gilje (1996), Auyero (2003), Badiou (2012), Dupuis-Deri (2010), Seferiades and Johnston, ed. (2012), Clover (2016), Meckfessel (2016), Ketchley (2017), Kadivar and Ketchley (2018), and Case (2018).
} 
black bloc ${ }^{3}$ actions about their experiences. The interviews are not meant to provide a causal explanation for the quantitative finding; they only begin to explore the positive relationship between riots and movement activity. Activists' accounts demonstrate remarkable phenomenological impacts derived from the act of intentionally stepping over the line of legitimized protest, in some cases being compared to the feeling of freedom itself. These "breakthrough moments," as one interviewee puts it, imbue activists with courage and an embodied sense of possibility that sustains long-term engagement in movements.

\section{THE PROBLEM WITH STRATEGIC NONVIOLENCE}

Since Gene Sharp's formative work, The Politics of Nonviolent Action (Sharp 1973), the field of study and practice of nonviolence resistance (NVS), also known as civil resistance studies, has grown to become an influential voice in the academy (see Chenoweth and Stephan 2011; Nepstad 2015) and among movement practitioners (see Engler and Engler 2016; Lakey 2018). The central intervention establishes a distinction between "strategic nonviolence" and "principled nonviolence." Rather than persuading people that violent resistance is morally problematic, NVS aims to demonstrate that social movement strategy oriented around nonviolent repertoires is the most effective method of leveraging social power and winning large-scale campaigns. In other words, nonviolence is not better because violence is immoral, nonviolence is better because it works better. The logic flows from Sharp's observation (one he shares with a great many social theorists) that political authority is dependent upon the consent of the governed-if subjects collectively withdraw their support for a government, the government's authority collapses (Sharp 1973). In and of itself, this observation has nothing to do with nonviolence, but Sharp and NVS scholars claim that the most effective way to achieve this type of leverage is through specifically nonviolent action. According to the argument, the key to movement success is the escalation of nonviolent demonstrations. Violent actions, the argument goes, lead to demobilization, thereby making them harmful to movements (ibid). There are two problems with the strategic nonviolence framing: the "nonviolence" part and the "strategic" part. I describe each in turn, and

\footnotetext{
${ }^{3}$ The black bloc is a leftwing protester tactic associated with anarchists in which activists wear black and cover their faces to make it difficult for police to distinguish individuals within the crowd; it is used as counter-surveillance in aggressive and illegal collective actions. See Avery-Natale (2010) and Dupuis Deri (2010).
} 
go on to address the limitations of the nonviolence framing in the quantitative component and the strategic framing in the qualitative component of this paper.

In the most prominent empirical work in the field, Chenoweth and Stephan claim to quantitatively validate the argument for strategic nonviolence (Chenoweth and Stephan 2011). Using their Nonviolent and Violent Conflicts and Outcomes (NAVCO) dataset, Chenoweth and Stephan find that nonviolent resistance is almost twice as likely as armed resistance to overthrow governments, a finding they attribute primarily to the superior capacity of nonviolent tactics to mobilize large numbers of people on a consistent basis (ibid). Subsequent studies using the same data find the "radical flank effect" of simultaneous violent and nonviolent movements within the same country to be negative, i.e., violent actions lead to lower chances for movement success, a mechanism which again is attributed to the demobilizing impact of violent tactics (Chenoweth and Schock 2015). However, these studies ignore riots and low-level violence.

When activists on the left debate violence and nonviolence today, they are typically arguing over rioting, property destruction, sabotage, street brawls with fascists, and other forms of unarmed physical confrontations. The "violent" campaigns in NAVCO, however, are composed of instances of armed struggle - literal warfare - and the dataset contains no measures for unarmed violence. When data on violent protests are added to NAVCO, it turns out that the vast majority of "nonviolent" campaigns - including four out of five successful campaigns - involved or were accompanied by major riots (Case 2018). Studies have also found that riots have a democratizing effect on otherwise nonviolent movements (Kadivar and Ketchley 2018). Still, findings derived from NAVCO are widely interpreted as applying to unarmed violent tactics and are frequently cited in activist communities and nonviolent direct action trainings to validate strict nonviolent discipline (see Engler and Engler 2016; Schneider 2012). Researchers have advanced this misunderstanding by applying NAVCO findings to tactics and movements that are not represented in the data. For example, despite NAVCO not measuring unarmed violence and only representing "maximalist" political campaigns, Chenoweth uses that data to argue that black bloc tactics during the \#J20 protests at Donald Trump's inauguration would hinder resistance to the Trump regime (see Chenoweth 2017). This example is especially salient since some nonviolentists claim to not consider property damage violence; the black bloc on J20 attacked property, not people. It was the "burned limousine 


\section{Benjamin S. Case}

and vandalized storefronts" that drew Chenoweth's criticism on the basis of nonviolence logic (ibid: $\mathrm{np}$ ).

Sharp's framing argument is that nonviolence is "a prerequisite to advantageous power changes" and that, "as a consequence, nonviolent discipline can only be compromised at the severe risk of contributing to defeat" (Sharp 1973: 70). Sharp and others in NVS point to a number of specific mechanisms that make violent tactics necessarily harmful to movements, e.g., that violence invites repression, negates the backfiring effect of repression, is a barrier to participation, and alienates public opinion (Chenoweth and Stephan 2011; Nepstad 2015; Schock 2005). All of these arguments relate to a single, central claim that violent tactics demobilize nonviolent actions. In this paper, I empirically test that claim using data on riots and nonviolence demonstrations in the US over 72 years.

The strategic component of strategic nonviolence comes with its own problems. While the "it works better" framing is compelling for activists who are interested in building power (myself included), it has also encouraged a mechanistic view of movement tactics. ${ }^{4}$ This position essentially approaches movements as one would a cookbook, as though we could generate predictably successful outcomes if only our inputs could be correctly measured. This appealing but ultimately unrealistic framing is particularly useful for formal social movement organizations and non-profits, especially as it relates to securing funding and avoiding criminalization, likely contributing to the near-ubiquitous rhetorical adoption of nonviolent discipline by movements today. Among other things, the strategic nonviolence approach is prone to overlook emotional and symbolic meanings, which connect struggles over longer time periods and distances-dynamics which are not always reflected in success rates for short-term campaign goals. By asking participants themselves about their experiences, we gain insight into the subjective importance of violent transgression and property destruction. These experiences reveal how the distinction between strategic and symbolic actions is at least as fuzzy as the violence/nonviolence binary.

Riots are commonplace in civilian uprisings and ignoring them only limits our ability to accurately conceptualize movement dynamics and their broader impacts. Taking a focused, empirical look at the contentious space of riots in social struggle - the grey areas between violence and nonviolence, between strategic and symbolic - can expand

\footnotetext{
${ }^{4}$ For a theory of nonviolent action that attempts to move beyond this mechanistic view, see Vinthagen (2015).
} 
our understandings and analyses of the ways in which movements challenge power from below.

\section{TERMINOLOGY AND QUALIFICATIONS}

The term "symbolic violence" is often associated with the social theory of Pierre Bourdieu; I use it differently. For Bourdieu, symbolic violence refers to systemic domination in society:

Symbolic violence is the coercion which is set up only through the consent that the dominated cannot fail to give to the dominator (and therefore to the domination) when their understanding of the situation and relation can only use instruments of knowledge that they have in common with the dominator, which, being merely the incorporated form of the structure of the relation of domination, make this relation appear as natural. (Bourdieu, 2000: 170)

In a way, Sharp's theory of strategic nonviolence is meant to break through Bourdieu's symbolic violence through the organized withdrawal of consent by the dominated. ${ }^{5}$ Bourdieu's symbolic violence flows from the dominator to the dominated and is primarily non-physical, based in institutions, knowledge, and norms; it is the way that systemic domination is infused in our lives and perpetuates itself through mindsets and behaviors. At the same time, there is a "close connection between symbolic violence and physical violence in the making and contesting of social order" and resistance to symbolic violence "not infrequently involves physical violence" (von Holdt 2012: 127). It is a form of this resistance that I explore in this paper. As we will see, the symbolism of the black bloc riot is intimately connected with a rupturing of Bourdieu's symbolic violence. However, I use the term "symbolic" not in Bourdieu's meaning, but to distinguish the physical transgression of the black bloc riot both from a purely "instrumental" view of violence and from a mechanical "strategic" view of nonviolence.

Admittedly, the term "riot" is messy. It is often used to denote chaos and is frequently deployed to discredit movements. Many things may be happening during the same protest action, and some participants would be loath to see their otherwise nonviolent actions described as a riot because a few windows got broken, especially when the media reliably

\footnotetext{
${ }^{5}$ Bourdieu is approaching power at a far higher level of analysis than Sharp, and Sharp's theory itself can be read as part of the knowledge-creation of the symbolic order, in other words as a facet of Bourdieu's symbolic violence. See Smith (2019).
} 


\section{Benjamin S. Case}

uses violent actions to disparage protests. The term riot can also take on racialized connotations (see Abu-Lughod 2007; Rakia 2018). The qualitative component of this study deals predominantly, though not exclusively, with the experiences of white people rioting, which is a parameter that should be kept in mind when applying the analysis in that section. The word "riot" is fraught, but also widely used worth reckoning with. As Thompson reminds us with his working definition of a riot"open-ended spaces where active experiments with violence became possible... and [thus] the production of politics became more explicit" (Thompson 2010: 25) - there is something different about protests that cross or threaten to cross the physically destructive line. In other words, it is not a line between nonviolent and violent as much as it is a line between avowedly nonviolent and not-necessarily-nonviolent.

Private property rights and police authority are sacred in liberal society, and publicly threatening them marks out an exceptional moment and space-what Shon Meckfessel refers to as the "eloquence" of property destruction and clashes with police (Meckfessel 2016). At the same time, not all riots push politics in the same direction; I am not seeking here to explore everything that could be called a riot, but a particular type of riot, based in Thompson's definition and the fairly stable repertoire of actions associated with it, i.e., throwing projectiles at police, breaking corporate windows, and setting things on fire. In the quantitative study, however, the operational definition of a riot is defined based on raw numbers and behavior (discussed further below). Furthermore, both quantitative and qualitative components of this paper are based on data from the US, and further research is required to expand its scope to other contexts. At the same time, it has been argued that if there is any place protester violence should backfire, it is the US (see Solnit 2011). As such, while this study is by no means universalizable, its findings are relevant to universal arguments around violence and nonviolence.

\section{DATA AND METHODS}

The strategic nonviolence argument is premised on the assumption that violent tactics demobilize nonviolent actions; I quantitatively test that claim.

In order to test the effect that riots have on nonviolent mobilizations, I use existing annual data for the United States from the Banks CrossNational Time-Series Data Archive (CNTS). This prominent dataset contains variables for riots and for nonviolent demonstrations, with data 
collection based on newspaper articles. The riot variable is defined as: "Any violent demonstration or clash of more than 100 citizens involving the use of physical force" (Wilson 2018:np). The nonviolent demonstrations variable is defined as: "Any peaceful public gathering of at least 100 people for the primary purpose of displaying or voicing their opposition to government policies or authority," and the data excludes "demonstrations of a distinctly anti-foreign nature" (ibid). Because these data are based on reporting from The New York Times, "they are somewhat biased geographically and limited in comprehensiveness" (ibid). Focusing on the US minimizes geographic and cultural limitations in CNTS data collection methods, and these data are otherwise sufficient for broadly testing the relationship between riots and nonviolent demonstrations.

This study uses annual CNTS data from the US between 1946 and 2017 (prior to 1946 there are significant gaps in the data), with a total of 72 observations. Using an annual measure over 72 years gives a wideangle view of the overall effects that riots have on nonviolent mobilizations, showing how movements have escalated and demobilized over time. The dependent variable is nonviolent demonstrations and the explanatory variable is riots. Because of the theoretical connection between riots and nonviolent protests (i.e., both collective modes of expressing discontent), it is highly unlikely that a relationship between these variables will be spurious. Nevertheless, the models include basic exogenous factors; I include GDP per capita and unemployment rates from the Bureau of Labor and Statistics as control variables.

I begin with an ordinary least squares (OLS) regression to test the relationship between riots and nonviolent demonstrations within the same year. However, NVS arguments claim that violent protest demobilizes subsequent nonviolent demonstrations. Therefore, I use a time-series analysis to capture the effect that riots have on nonviolent mobilizations in the following year. I use an autoregressive integrated moving average (ARIMA) model, with first order moving average, differenced once-i.e., an ARIMA $(0,1,1)$ model. ${ }^{6}$ ARIMA modeling is

\footnotetext{
${ }^{6}$ Diagnostic examination of correlograms, auto-correlation function (ACF), and partial auto-correlation function (PACF) plots indicate either a first order autocorrelation function or first order moving average. An ARIMA $(1,1,0)$ model produces a positive, statistically significant coefficient. The residuals for this model conform to white noise, but the autocorrelation function is negative, which can indicate errors in the model. I therefore used a first order moving average instead of autocorrelation; an ARIMA $(0,1,1)$ model, which in any case produces similar results. For the sake of overfitting, I tested an ARIMA $(1,1,1)$ model as well; applying this model, the riots coefficient is still positive and statistically significant, however, the Portmanteau test falls outside the confidence
} 


\section{Benjamin S. Case}

often used for predictive econometrics, but is also useful for studying the relationship between social phenomena over time (Box-Steffensmeir et al. 2014). The model accounts for non-stationarity, and I use a single lag, since, given the scale of the data, a riot in one year is unlikely to have an impact on nonviolent protest two years removed if it does not have an impact on nonviolent protest in the subsequent year.

\section{RESULTS}

Results from the linear regression show a positive, statistically significant relationship between the riot and nonviolent demonstration variables at the 99 percent confidence interval (see Table 1). In the US, each riot is associated with an additional 1.02 nonviolent demonstration within the same year. GDP is also statistically significant, but the coefficient is approximately zero. In addition, the relationship between riots and nonviolent demonstrations works in both directions, i.e., nonviolent protest also leads to higher levels of riots, with the coefficient being slightly lower in reverse. In other words, years with increased riots also see increases in nonviolent protest, and vice versa, indicating that violent and nonviolent protest are mutually constitutive of moments of uprising. This initial finding is especially meaningful due to the annual timeframe of the data, since waves of protest can wax and wane within a year.

The time-series coefficient is positive and statistically significant at the 99 percent confidence interval (see Table 1), meaning that instances of riots are correlated with higher rates of protest in the following year. Controlling for GDP and unemployment fluctuations, each riot in a given year is associated with 0.56 additional nonviolent demonstrations in the following year. The exogenous factors have no statistical impact on the model. Unlike the linear regression results, ARIMA model is not statistically significant when reversed, meaning nonviolent demonstrations have no significant effect on the number of riots in the following year.

Shocks to riots and to nonviolent demonstrations occur in different proportions at times, but in nearly all cases they rise and fall contemporaneously. There are almost no instances of a shock to one variable in isolation from the other (see Figure 1). It is important to consider the time-frame of the data when interpreting these results, but

bands. I therefore opted for an ARIMA $(0,1,1)$ model, which diagnostics indicate is the most appropriate. 
increases in mobilization of each type of collective action tend to occur in spikes (as opposed to gradual fluctuations) and occur together, indicating that riots and nonviolent demonstrations in uprisings are related to each other and/or to similar causes, exogenous influences, and collective action frames. Put simply, moments of civilian uprising comprise both riots and nonviolent demonstrations.

\section{Table 1.}

\section{OLS}

$\operatorname{ARIMA}(0,1,1)$

Riots

GDP per capita

Unemployment

Observations:

R2:

Adj R2:

$\begin{array}{ll}1.02 * * * & 0.56 * * * \\ (0.17) & (0.11) \\ 0.00 * * * & 0.00 \\ (0.00) & (0.00) \\ -2.56 & -0.64 \\ (0.98) & (2.08)\end{array}$

72

0.45

0.43

*** Correlation is significant at the 0.01 level (2-tailed)

Figure 1. Riots and nonviolent demonstrations in the USA, 1946-2017.

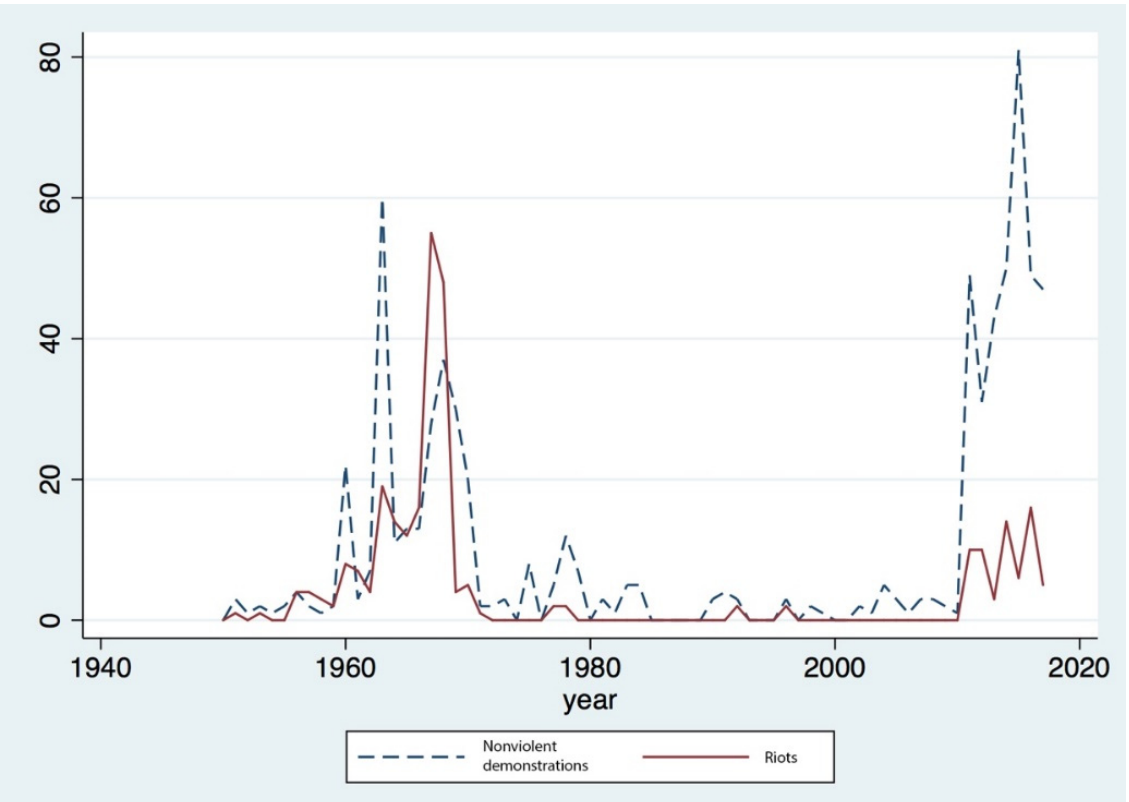




\section{Benjamin S. Case}

Linear regression shows a statistically significant and positive relationship between riots and nonviolent demonstrations, and timeseries analysis of annual data reveals that riots are associated with increases in nonviolent demonstrations over time. Riots do not demobilize movements; in the aggregate they are associated with increased mobilization. In order to investigate the positive effect that riots can have on movements over time, we look to the experiences of rioters themselves.

\section{IN-DEPTH INTERVIEWS}

To explore the riot qualitatively, I interview twenty-seven anarchists in the US about their experiences with violent protest, and in particular with black bloc tactics. Demographically, thirteen interviewees were men (including one transman), ten were women, and four identified as gender nonconforming. Twenty were white (several of those self-identifying as white were also Jewish), three were Black, two were Latino, one was Asian-American, and one identified as multi-racial. I use accurate gender pronouns, but names have been changed and locations omitted to protect participants' identities.

I draw on all interviews in my analysis but focus here on the narratives of two participants, both queer white women. ${ }^{7}$ I choose to focus on these narratives in part because of their age - both between 30 and 50 years old-which gives added traction to their reflections on the impact these actions have had on their life trajectories and activist careers. While disclosing their precise ages and current occupations could compromise their privacy, both are embedded in activist communities and devote their professional lives to social justice. It is worth noting also that most riots in the quantitative study discussed above did not involve black blocs. As black bloc participants do not speak for all rioters, this component of the study is not meant to explain the mechanisms of all

\footnotetext{
${ }^{7}$ Gendered analysis of the riot and of the black bloc bears the attention of its own study, but in this case I choose to focus on the stories of two queer white women in part because most respondents were white and many were queer, and in order to mitigate potential biases around experiences of violence through a hegemonic masculine lens. Some interviewees spoke to the presence of toxic or aggressive masculinity in the bloc, but most associated this behavior with problematic individuals, and, according to some participants, in some instances possibly even agent provocateurs. As one interviewee put it: "Within an affinity group or collective, at least the groups I've been part of, there is a tremendous amount of work around gender equity, and it's never perfect, but I don't feel like action machismo is a problem we run into. But there are always a couple people who are bloc-ed up who aren't accountable to anyone."
} 
riots, but rather to expand the possibilities for understanding violent protest as part of the process of social change through the words of participants in a particular type of riot.

\section{SYMBOLIC VIOLENCE: IN THE WORDS OF TWO RIOTERS}

Violence, according to Hannah Arendt, "is distinguished by its instrumental character" (Arendt 1970: 46). We tend to think of violence as Arendt does, as an instrument to accomplish something tangible. Early studies of movements understood it the same way: "Violence should be viewed as an instrumental act, aimed at furthering the purposes of the group that uses it when they have some reason to think it will help their cause" (Gamson 1975: 81). Ironically, the strategic nonviolence lens now approaches all movement actions instrumentally, and argues against the use of violent tactics precisely on the basis that they are not instrumentally effective. However, a central theme that emerges in interviews with black bloc participants is how the violence of the riot is primarily symbolic, not instrumental.

The collective violation of the sanctity of private property and police authority are deeply symbolic for participants. There are still instrumental qualities of particular actions, of course; looting, for example, can have both instrumental and symbolic qualities and is highly selective in terms of target (Simiti 2012; Kerner et al. 1968). Unarresting $^{8}$ a person is principally about keeping the potential arrestee out of police custody, but, as we will see, there is an accompanying sense of empowerment for the unarrestors which is deeply symbolic. For many participants, the experience of participating in a violent protest has deep, lasting phenomenological effects that supersede any direct material outcome.

Em, an anarchist who has participated in numerous black bloc actions, discussed the sensation of collectively breaking fundamental rules around private property and police authority:

It was absolutely terrifying, but it also had that feeling! You know, once you crack open that understanding of, "am I allowed to do this and that?"-once a fissure opens in that, there is a whole other range of possibilities before you, and it's so beautiful. It's thrilling... like, oh my god, the world is so much more interesting, and there is so much more to be done.

\footnotetext{
${ }^{8}$ Also called "de-arresting."
} 


\section{Benjamin S. Case}

Describing the feeling, she added: "like, is this fear or is this freedom?" For Em, stepping over the line past peaceful protest was frightening but also exhilarating, and in it she glimpsed a more beautiful and expansive world - perhaps the feeling of freedom itself. For her, the sensation lived in the moment, but had a lasting impact:

I think there are aspects of my personality that have been formed by those breakthrough moments... There is an aspect to radicalism that says, "better things are possible" and that gives you the ability to predicate other things on that assumption, and that isn't always tangible to you if you haven't had those concrete experiences. Otherwise it's just ideological. But I think once you've had those singular emotional experiences, and had them with a community... it changes the way you understand things to be. Sometimes that ends up being institutionalized and sometimes it ends up being a high you chase, and in my case it's more just been like I am not afraid to demand that the world be different, because I've seen the potential for other things. And I take a lot of comfort from that. I don't anticipate that I'll be able to see the changes I envision in my life or my child's life, but just understanding that power structures as they are now are not fossilized and not permanent, I feel like all of these things can be broken and transformed, and I think that's a real gift.

As Martin Buber put it: "Convictions based on pure thinking cannot be decisive in themselves" (Buber 1952: 62). For Em, the embodied understanding of the need and possibility for a new world is elevated past what would be possible simply through intellectual learning. The feeling of expansiveness and beauty that accompanied physically forceful collective actions is in and of itself important to focus on. Even defenders of riots typically describe them as destructive forces-perhaps destroying what needs to be destroyed, but destructive nonetheless. Riots might be destructive, but participants also describe a generative sensation that both sustains their long-term political engagement and imbues them with a vision that, as the anti-globalization movement insisted, another world is possible.

Another respondent, $\mathrm{Zi}$, relates a similar feeling combining fear and empowerment during her first black bloc: "It was kind of scary... it was like, oh shit there's a fire in the middle of the street! And in that moment, it felt like the tables had turned, you know? ... I remember being scared 
but also enlivened." In particular, Zi described unarresting a comrade during that first experience in a riot leaving her transformed:

I felt really empowered by being part of a group like that. And that was something I wanted people to know was possible. And the unarrest, you know? That we didn't have to just go along with the power over us. That we could physically remove ourselves from that kind of power and violence and control, feeling really just a fundamental shift in my capitulation to authority. I was in kind of an abusive relationship at that time, and it was the end of my tolerance for that. It just seemed like a lot more was possible.

Through the act of fighting a friend out of police custody, $\mathrm{Zi}$, in the moment, organically connected the coercive authority of the state with abusive interpersonal dynamics. The internalized empowerment of resisting one led to a personal transformation that affected her clarity, ability, and drive to resist the other. To view that particular black bloc action instrumentally in terms of whether or not it advanced a short-term strategic goal would miss the point. Zi reported the sensation of the riot instilling in her a sense of empowerment that not only had a lasting impact on her political engagement, but transformed her relational personality.

Georges Sorel famously advocated the use of violent tactics to rouse the complacent middle class to class war (Sorel 1950). To Sorel, the growth of a liberal middle class was preserving the capitalist system by blunting its fundamental antagonisms and giving people hope in the system, what in the US came to be called "the American dream." In his words, violent action by the proletariat against the middle class could "so operate on the middle class as to awaken them to a sense of their own class sentiment" and allow the class war to proceed (ibid: 90). Thompson notes the relevancy of Sorel's theory today, and also that it "needs to be revised slightly" in order to turn middle class "dissident energies" against the system (2010: 5). In the words of black bloc rioters, we see evidence of this revision-both a connection to Sorel's theory and its inversion.

For Sorel, violence had to be done to members of the middle class in order to raise their consciousness in terms of their interest in fighting to preserve the system. In this case, the violence of the riot has a similar consciousness-raising effect, but as a result of violence being done by the rioter (many of whom are white and come from middle class backgrounds), raising their own consciousness in terms of their interest in fighting back against the system. The key is the empowering sensation 


\section{Benjamin S. Case}

of physically opposing authority, which worked on the one hand to counter the pervasive sense of alienation both in society and in conventional protest, and on the other hand to clarify antagonisms with authority. As Em put it, "It only takes one or two experiences being beaten up by cops in the streets to really, really understand in a physical, almost animal way, that these people are not here to help you."

$\mathrm{Zi}$ spoke repeatedly about the heightened, exciting, and cohesive feeling of being in a group that was explicitly crossing the property destruction line. In one remarkable coincidence, the comparative power of the riot experience was personified when she happened to spot an old friend at a permitted Earth Day march that Zi's black bloc had broken away from. Years prior in another city, before $\mathrm{Zi}$ had radicalized, she and this estranged friend had attended many conventional protests together:

And she was standing there, watching the protest go by on the other sidewalk. And she was crying. Just watching the protest and crying at how awful the world was or something... And I was just like, fuck that - just crying in response to this crisis we're in. Because... a couple years ago I would have been there too. I would have been on the sidelines right next to her, feeling overwhelmed and hopeless and crying. But instead I was in a cohesive unit, energized and running down the street trying to change things in a different way.

For $\mathrm{Zi}$, the sensation was formative in that it created an embodied sense of radicality that raised consciousness and fueled her through her political life. During the interview, she became visibly animated and smiled excitedly when describing the heightened sensation of participating in the riot, revealing how powerful those moments are for her even today. Those feelings retained their positive affect despite $\mathrm{Zi}$ also acknowledging that in the immediate material sense the actions she was describing made next to no difference: negligible property destruction, likely covered by insurance or the taxpayer, and not directly impacting the "crisis" she referred to above.

In fact, the majority of respondents, including the two quoted in this paper, are strategically-minded activists who voiced frustration with insufficient attention to strategy on the left. As Em put it, after describing a seemingly successful militant action in which their group initially backed down lines of riot police and occupied a bridge: "And that's a great metaphor for the left, right? It's like, we take the bridge, and now what?" She went on: "We can have these militant marches or even, you know, take over the road or a bridge for a few hours, but we don't always 
have the structure or numbers to take the next step. How do you turn these actions into levers of real political power?" This measured appraisal contradicts the notion that riots are spontaneous and irrational outbursts of mob violence by people who are devoid of strategic sensibility, and also points toward the need to situate the riot's symbolic importance in conjunction with a strategic outlook.

The riot as discussed here is primarily a symbolic act. Or, more precisely, it is a collection of symbolic acts. As $\mathrm{Zi}$ and many other respondents alluded to, smashing a corporate window during a protest is not really about destroying that window in the tactical sense, and, in fact, is barely about the cost of replacing it - it is about smashing a concept. Burning barricades or throwing rocks at the police in some circumstances have tactical applications, but in most cases, these acts symbolize a fight more than they actually engage in the fight. Rock-throwing cannot defeat even moderately armed police in an unbridled confrontation of force, and dumpster fires are not terribly difficult to put out or move. Even major riots that escalate to widespread property destruction could be put down with the full application of deadly force that the police (and certainly the military) have at their disposal. The police make their own strategic and emotional calculations about their use of force, not the least of which is fear of riots spreading or developing into complete social breakdown. The physical violence on both sides of the riot is therefore marked by the quality of restraint.

With respect to the scope of political violence, the riotous actions discussed by black bloc participants are so minimal they can barely be considered violent - and indeed many argue that property destruction is not in fact violence. But to say that breaking a window or torching a cop car is not violent would be misleading; there is a palpable and undeniable difference between a protest in which property is physically attacked and one in which physical destruction is off limits. The violence is symbolic; public dissent-as-property-destruction symbolizes the inherent violence required to forcefully resist structural violence. And the feeling of violating the sanctity of private property and of police authority, the twin pillars of liberal society, delivers for many a transcendent sensation. These forms of low-level violent resistance symbolize the fight - and one's position, perhaps identity, in it - in a way that can be felt in the body. Amidst a bureaucratic neoliberal system that is consistently and relentlessly disempowering, feeling that embodied power can be transformative.

It is not simply neoliberalism in some abstract sense that is disempowering, but also social movement organizations and strategies 


\section{Benjamin S. Case}

that are shaped by neoliberal constraints. The physically transgressive actions of the black bloc take place in reference to disempowering actions in conventional protest and movement organizations, as Zi's quote above testifies to. Em described how the disempowering quality of conventional organizing can have deep impacts on a person's identity; the black bloc ${ }^{9}$ was a mode of action that countered the disempowerment of the system with the embodiment of fighting back, contributing to the formation of a more empowered identity:

There are so many experiences of disempowerment. Including in movement organizing. I didn't personally feel like I had power in any of the political protests I saw and was part of... I think there are important parts of identity that are formed through experiences of power, either being repressed by power or having the opportunity to wield power.

Some have attempted to conceptualize a riot as the direct conduit to broad social transformation (e.g., The Invisible Committee 2007). But there are obvious limitations to the ability of a riot as discussed here to directly transform society. However, in the words of black bloc participants we see how the riot has the direct ability to transform individuals and collectives. Riots can symbolize the embodied persistence of political struggle in society and infuse participants with a visceral sense of which side they are on. The riot might not in and of itself transform broader society, but then again no single tactic does. Black bloc participants describe how the riot imbues participants with a lasting empowerment and the visceral sense that society can be changed for the better, sustaining long-term engagement in political work.

\section{CONCLUSION}

This paper empirically tests the relationship between riots and protests and finds evidence that riots have positive effects on levels of nonviolent demonstration over time. This is not to say that a riot will necessarily lead to increased nonviolent protest - there are certainly instances in which protester violence demobilizes nonviolent protest. The point of this finding is not that violence is more effective than nonviolence, but

\footnotetext{
${ }^{9}$ Em acknowledged the historically tactical application of the black bloc to defend squats in Germany, and described similar tactical applications she had participated in.

Nevertheless, in her experiences related in this interview, the most transformative aspects of participation in black blocs resided in their subjective quality.
} 
rather that juxtaposing them as ideal forms can limit our ability to see social movements holistically. Both more and less violent actions typically co-exist during moments of uprising, and in terms of broad trends, riots are empirically associated with increased nonviolent mobilizations.

There are likely multiple explanations for the mobilizing impact of riots. The experiences of activists who have directly participated in riots through the black bloc tactic indicate toward one of them; the subjective experience of collectively interrupting the sanctity of private property and police authority. It has been well argued that riots can give movements material leverage via the credible threat of mass unrest (e.g., Piven and Cloward 1978; Meckfessel 2016; Seferiades and Johnston ed. 2012), and in some circumstances, riots can play a crucial tactical role in conjunction with nonviolent actions (Ketchley 2017). My quantitative finding lends weight to these positions. On a grander scale, there are rare examples of "historical riots" that topple governments as the culmination of social struggle, upending structural power (Badiou 2012). But the riot can be the catalyst more easily than it can be the endgame. Most previous studies overlook the importance of the sensation of rioting for the participant. This subjective impact is especially powerful in a neoliberal context characterized by increasing dimensions of alienation. The "disruptive deficit" of movements today - protest actions that are merely about the appearance of disruption - not only materially weakens movements, it is felt by participants, sapping them of their vision and resolve and contributing to disempowered identities (Seferiades and Johnston 2012). On the other hand, the experience of physically transgressive moments, or "open-ended spaces" involving "active experiments with violence" (Thompson 2012: 25), viscerally counters alienation and disrupts the sense of disruptive deficit. The long-term impacts on participants' commitment to social justice, sense of possibility, personal empowerment, and continued participation in nonviolent actions break apart the false binaries of violent/nonviolent and strategic/symbolic actions.

This paper demonstrates an empirically mobilizing effect of riots in the US. In addition, activists who have participated in black blocs report that the experience of rioting has played a radically sustaining role in their activism. Moments of physical confrontation have lasting phenomenological impacts, in this case heightening, and in a certain sense creating, an empowered political consciousness. Riots can thereby have symbolic power, representing the visceral reality of social struggle. The effects of the riot on participants are all the more pronounced in a 


\section{Benjamin S. Case}

neoliberal environment in which it is more and more difficult to tell form from content in social movement actions. Violence in protests, even very low-levels of violence, exists in constant comparison to an ideal of nonviolent struggle on the one hand and the overwhelming brutality of systemic violence on the other, marking out an interstitial symbolic space where politics are clarified and, in a sense, new political subjects are born.

\section{REFERENCES}

Abu-Lughod, Janet L. 2007. Race, Space, and Riots in Chicago, New York, and Los Angeles. New York: Oxford University Press. https://doi.org/10.1093/acprof:oso/9780195328752.001.0001

Arendt, Hannah. 1970. On Violence. New York: Harcourt, Inc.

Auyero, Javier. 2003. Contentious Lives: Two Argentine Women, Two Protests, and the Quest for Recognition. Durham: Duke University Press. https://doi.org/10.1215/9780822384366

Avery-Natale, Edward. 2010. We're Here, We're Queer, We're Anarchists': The Nature of Identification and Subjectivity Among Black Blocs. Anarchist Developments in Cultural Studies. 1: 95-115. https://doi.org/10.4135/9781848608252.n22

Badiou, Alain. 2012. The Rebirth of History: Times of Riots and Uprisings. Trans. Gregory Elliott. New York: Verso.

Banks, Arthur S., and Kenneth A. Wilson. 2017. Cross-National Time-Series Data Archive. Databanks International. Jerusalem, Israel.

Bourdieu, Pierre. 2000. Pascalian Meditations. trans. Richard Nice. Stanford: Stanford University Press.

Box-Steffensmeier, Janet, John R. Freeman, Matthew P. Hitt, and Jon C. W. Pevehouse. 2014. Time Series Analysis for the Social Sciences. New York: Cambridge University Press. https://doi.org/10.1017/cbo9781139025287

Buber, Martin. [1952] 1973. On Zion: The History of an Idea. London: Horovitz Publishing Co.

Case, Benjamin S. 2018. Riots as Civil Resistance: Rethinking the Terms of 'Nonviolent' Struggle. Journal of Resistance Studies. 4(1): 9-44.

Chenoweth, Erica. 2017. Violence Will Only Hurt the Trump Resistance. New Republic. February 7. (https://newrepublic.com/article/140474/ violence-will-hurt-trump-resistance) Accessed March 15, 2017.

Chenoweth, Erica, and Kurt Schock. 2015. Do Contemporaneous Armed Challenges Affect the Outcomes of Mass Nonviolent Campaigns? Mobilization. 24(4): 427-51. https://doi.org/10.17813/1086-671x-20-4$\underline{427}$ 
Chenoweth, Erica, and Maria J. Stephan. 2011. Why Civil Resistance Works. New York: Columbia University Press. https://doi.org/10.1080/10402659.2014.876333

Clover, Joshua. 2016. Riot. Strike. Riot. Brooklyn: Verso.

Dupuis-Déri, Francis. 2010. The Black Blocs Ten Years after Seattle: Anarchism, Direct Action, and Deliberative Practices. Journal for the Study of Radicalism. 4(2): 45-82. https://doi.org/10.1353/jsr.2010.0005

Engler, Mark, and Paul Engler. 2016. This Is an Uprising: How Nonviolent Revolt Is Shaping the $21^{\text {st }}$ Century. New York: Nation Books.

Gamson, William. 1975. The Strategy of Social Protest. Homewood: The Dorsey Press.

Gilje, Paul. 1996. Rioting in America. Indianapolis, IN: University of Indiana Press.

Guevara, Ernesto. [1961] 2006. Guerrilla Warfare. New York: Ocean Press.

The Invisible Committee. 2007. The Coming Insurrection. Los Angeles: Semiotext(e).

Kadivar, Mohammad Ali, and Neil Ketchley. 2018. Sticks, Stones, and Molotov Cocktails: Unarmed Collective Violence and Democratization. Socius. 4: 1-16. https://doi.org/10.31235/osf.io/tdcae

Kerner, Otto, et al. [1968] 2016. Report of the National Advisory Commission on Civil Disorders. Princeton: Princeton University Press.

Ketchley, Neil. 2017. Egypt in a Time of Revolution: Contentious Politics and the Arab Spring. Cambridge: Cambridge University Press. https://doi.org/10.1017/s0020743819000187

Lakey, George. 2018. How We Win: A Guide to Nonviolent Direct Action Campaigning. Brooklyn: Melville House.

Mao, Zedong. [1937] 1978. On Guerrilla Warfare. trans. Samuel Griffith. New York: Anchor Press.

McCarthy, John D., and Mayer Zald. 1977. Resource Mobilization and Social Movements: A Partial Theory. American Journal of Sociology. 82(6). https://doi.org/10.1086/226464

Meckfessel, Shon. 2016. Nonviolence Ain't What It Used to Be: Unarmed Insurrection and the Rhetoric of Resistance. Chico: AK Press.

Nepstad, Sharon Erikson. 2015. Nonviolent Struggle: Theories, Strategies, and Dynamics. New York: Oxford University Press.

Piven, Frances Fox, and Richard Cloward. 1978. Poor People's Movements: Why They Succeed, How They Fail. New York: Vintage. https://doi.org/10.1086/ahr/83.3.841

Rakia, Raven. 2018. Black Riot. The New Inquiry. 68.

Schneider, Nathan. 2012. Principle: Maintain Nonviolent Discipline. in Beautiful Trouble: A Toolbox for Revolution. Boyd, ed. New York: OR Books. https://doi.org/10.2307/j.ctt1bkm5nd.59 


\section{Benjamin S. Case}

Simiti, Marilena. 2012. The Volatility of Urban Riots. In Violent Protest, Contentious Politics, and the Neoliberal State. Seferiades and Johnston, eds. Burlington: Ashgate. https://doi.org/10.4324/9781315548104

Schock, Kurt. 2005. Unarmed Insurrections: People Power in Nondemocracies. Minneapolis: University of Minnesota Press. https://doi.org/10.1111/j.1468-2508.2005.00361 5.x

Sharp, Gene. 1973. The Politics of Nonviolent Action. Boston: Porter Sargent Publishers.

Seferiades, Seraphim, and Hank. Johnston, eds. 2012. Violent Protest, Contentious Politics, and the Neoliberal State. Burlington: Ashgate. https://doi.org/10.4324/9781315548104

Smith, Marcie. 2019. Change Agent: Gene Sharp's Neoliberal Nonviolence. Nonsite. $\quad 28 . \quad$ (https://nonsite.org/article/change-agent-gene-sharpsneoliberal-nonviolence-part-one\#) Accessed May 17, 2019.

Snow, David, and Robert Benford. 1988. Ideology, Frame Resonance, and Participant Mobilization. International Social Movmement Research. 1: 197-217.

Solnit, Rebecca. 2011. Throwing Out the Master's Tools and Building a Better House: Thoughts on the Importance of Nonviolence in the Occupy Revolution. Common Dreams.

(https://www.commondreams.org/views/2011/11/14/throwing-outmasters-tools-and-building-better-house-thoughts-importance) Accessed September 12, 2019.

Sorel, Georges. [1950] 2004. Reflections on Violence. T. E. Hulme and J. Roth, trans. Glencoe, IL: The Free Press.

Thompson, AK. 2010. Black Bloc, White Riot: Anti-Globalization and the Genealogy of Dissent. Oakland: AK Press.

Vinthagen, Stellan. 2015. A Theory of Nonviolent Action: How Civil Resistance Works. London: Zed Books. https://doi.org/10.1080/10402659.2018.1553557

von Holdt, Karl. 2012. The Violence of Order, Orders of Violence: Between Fanon and Bourdieu. Current Sociology. 61(2): 112-31.

Wilson, Kenneth. A. 2018. User's Manual for Cross-National Time Series Archive. Databanks International. Jerusalem, Israel. 